\title{
Forebrain $\mathrm{CRF}_{1}$ Modulates Early-Life Stress-Programmed Cognitive Deficits
}

\author{
Xiao-Dong Wang, ${ }^{1}$ Gerhard Rammes, ${ }^{1,2}$ Igor Kraev, ${ }^{3}$ Miriam Wolf, ${ }^{1}$ Claudia Liebl, ${ }^{1}$ Sebastian H. Scharf, ${ }^{1}$ \\ Courtney J. Rice, ${ }^{4}$ Wolfgang Wurst, ${ }^{5,6}$ Florian Holsboer, ${ }^{1}$ Jan M. Deussing, ${ }^{1}$ Tallie Z. Baram, ${ }^{4}$ Michael G. Stewart, ${ }^{3}$ \\ Marianne B. Müller, ${ }^{1}$ and Mathias V. Schmidt ${ }^{1}$ \\ ${ }^{1}$ Max Planck Institute of Psychiatry, 80804 Munich, Germany, ${ }^{2}$ Department of Anesthesiology, Technische Universität, Klinikum rechts \\ der Isar, 81675 Munich, Germany, ${ }^{3}$ Department of Life Sciences, The Open University, Milton Keynes MK7 6AA, United Kingdom, ${ }^{4}$ Departments of \\ Anatomy/Neurobiology, Pediatrics and Neurology, University of California, Irvine, Irvine, California 92697-4475, ${ }^{5}$ Institute of Developmental Genetics, \\ Helmholtz Center Munich, German Research Center for Environmental Health, 85764 Neuherberg, Germany, and ${ }^{6}$ Deutsches Zentrum für \\ Neurodegenerative Erkrankungen, German Center for Neurodegenerative Diseases, 80336 Munich, Germany
}

Childhood traumatic events hamper the development of the hippocampus and impair declarative memory in susceptible individuals. Persistent elevations of hippocampal corticotropin-releasing factor (CRF), acting through CRF receptor $1\left(\mathrm{CRF}_{1}\right)$, in experimental models of early-life stress have suggested a role for this endogenous stress hormone in the resulting structural modifications and cognitive dysfunction. However, direct testing of this possibility has been difficult. In the current study, we subjected conditional forebrain $\mathrm{CRF}_{1}$ knock-out $\left(\mathrm{CRF}_{1}-\mathrm{CKO}\right)$ mice to an impoverished postnatal environment and examined the role of forebrain $\mathrm{CRF}_{1}$ in the long-lasting effects of early-life stress on learning and memory. Early-life stress impaired spatial learning and memory in wild-type mice, and postnatal forebrain CRF overexpression reproduced these deleterious effects. Cognitive deficits in stressed wild-type mice were associated with disrupted long-term potentiation (LTP) and a reduced number of dendritic spines in area CA3 but not in CA1. Forebrain $\mathrm{CRF}_{1}$ deficiency restored cognitive function, LTP and spine density in area CA3, and augmented CA1 LTP and spine density in stressed mice. In addition, early-life stress differentially regulated the amount of hippocampal excitatory and inhibitory synapses in wild-type and $\mathrm{CRF}_{1}$-CKO mice, accompanied by alterations in the neurexin-neuroligin complex. These data suggest that the functional, structural and molecular changes evoked by early-life stress are at least partly dependent on persistent forebrain $\mathrm{CRF}_{1}$ signaling, providing a molecular target for the prevention of cognitive deficits in adults with a history of early-life adversity.

\section{Introduction}

Early-life adverse events increase the danger of developing psychopathologies (Sadowski et al., 1999; Schenkel et al., 2005; Evans and Schamberg, 2009) in adult individuals with genetic risk factors (Feder et al., 2009), including specific polymorphisms and haplotypes of the corticotropin-releasing factor (CRF) gene (Smoller et al., 2005) and the CRF receptor $1\left(C R F_{1}\right)$ gene (Bradley et al., 2008; Tyrka et al., 2009). The hippocampus, a region essential for the regulation of the hypothalamic-pituitary-adrenal (HPA) axis and processing of spatial information, undergoes critical development early in life and is vulnerable to stress (Avishai-

\footnotetext{
Received May 5, 2011; revised July 14, 2011; accepted Aug. 6, 2011.

Author contributions:X.-D.W., J.M.D., T.Z.B., M.B.M., and M.V.S. designed research;X.-D.W., G.R.,I.K., M.W.,C.L., S.H.S., and M.V.S. performed research; C.J.R., W.W., J.M.D., T.Z.B., and M.G.S. contributed unpublished reagents/ analytic tools; X.-D.W. and G.R. analyzed data; X.-D.W., F.H., J.M.D., T.Z.B., M.G.S., M.B.M., and M.V.S. wrote the paper.

This work was supported by the European Community's Seventh Framework Program (FP7, Project No. 201600), the Bundesministerium für Bildung und Forschung within the framework of the NGFN-Plus (National Genome Research Network) (FKZ: 01GS08151 and 01GS08155) and by the Initiative and Networking Fund of the Helmholtz Association in the framework of the Helmholtz Alliance for Mental Health in an Ageing Society (HA-215). We thank Daniela Harbich, Claudia Kühne, Bianca Mayer, Marcel Schieven, and Stefanie Unkmeir for their technical assistance.

Correspondence should be addressed to Xiao-Dong Wang, Max Planck Institute of Psychiatry, RG Neurobiology of Stress, Kraepelinstraße 2-10, 80804 Munich, Germany. E-mail: wangxd@mpipsykl.mpg.de.

DOI:10.1523/JNEUROSCI.2259-11.2011

Copyright $\odot 2011$ the authors $\quad 0270-6474 / 11 / 3113625-10 \$ 15.00 / 0$
}

Eliner et al., 2002; Kim and Diamond, 2002; Lupien et al., 2009). In rodents, psychological stress during the first 2 weeks of life impairs hippocampus-dependent spatial learning and memory (Oitzl et al., 2000; Aisa et al., 2007; Rice et al., 2008), disrupts hippocampal long-term potentiation (LTP) (Champagne et al., 2008; Bagot et al., 2009; Ivy et al., 2010), and reduces dendritic complexity in hippocampal neurons later on (Brunson et al., 2005; Oomen et al., 2010).

In the hippocampus, CRF is released from inhibitory interneurons (Chen et al., 2001), binds with high affinity to $\mathrm{CRF}_{1}$ abundant in dendritic spines of pyramidal neurons (Chen et al., 2004a), and modulates neuronal function (Aldenhoff et al., 1983; Sheng et al., 2008) and cognition (Radulovic et al., 1999; Row and Dohanich, 2008). Interestingly, the levels of hippocampal CRF and $\mathrm{CRF}_{1}$ are much higher during the second and third weeks after birth compared with those in adulthood (Avishai-Eliner et al., 1996; Chen et al., 2001). Acute stress differentially activates hippocampal neurons in immature and adult brains, which is dependent on $\mathrm{CRF}_{1}$ (Chen et al., 2006). Early-life stress evokes enduring elevations of hippocampal CRF (Ivy et al., 2010) and may disrupt hippocampal $\mathrm{CRF}_{1}$ expression (O'Malley et al., 2011). Moreover, central administration of CRF to neonatal rats recapitulates the effects of early-life stress on cognition and hippocampal morphology (Brunson et al., 2001), whereas postnatal 
$\mathrm{CRF}_{1}$ antagonism prevents these effects (Ivy et al., 2010) and enhances spatial performance (Fenoglio et al., 2005) in adult rats. Hence, hippocampal $\mathrm{CRF}_{1}$ signaling may play an essential role in modulating the persistent programming effects of early-life stress on cognition.

While there is already some evidence for the involvement of the CRF-CRF ${ }_{1}$ system in mediating the effects of early-life stress on cognition, previous pharmacological approaches were limited with regard to regional specificity. Therefore, we here used transgenic mouse lines with conditional $\mathrm{CRF}_{1}$ deficiency (Müller et al., 2003) or CRF overexpression (Lu et al., 2008) specifically in forebrain regions to investigate the role of hippocampal $\mathrm{CRF}_{1}$ signaling in early-life stress-induced later-life cognitive impairments. A novel mouse model of early-life stress was used (Rice et al., 2008), in which the mother-pup interaction is disrupted by an impoverished postnatal environment. We examined whether forebrain CRF overexpression would reproduce the effects of early-life stress on spatial learning and memory during adulthood, and whether forebrain $\mathrm{CRF}_{1}$ inactivation would prevent the functional, structural, and molecular abnormalities induced by earlylife stress.

\section{Materials and Methods}

Animals. Male transgenic mice with postnatal inactivation of the $\mathrm{Crf}_{1}$ gene in forebrain neurons (referred to as $\mathrm{CRF}_{1}$-CKO hereafter) were generated as described previously (Müller et al., 2003; Wang et al., 2011). To generate a mouse line with forebrain-restricted overexpression of CRF in principal neurons, $R 26^{+/ f l o p C r f}$ mice were crossed to CaMKII $\alpha$ Cre mice (Lu et al., 2008). Male R2 $6^{\text {flop Crffflop Crf }}$ CaMKII $\alpha$-Cre mice (referred to as CRF-COE hereafter) were obtained in the F2 generation. $\mathrm{CRF}_{1}$-CKO and CRF-COE mice were kept on a mixed $129 \mathrm{~S} 2 / \mathrm{Sv} \times$ C57BL/6J background.

Adult female $\mathrm{CRF}_{1}$-EGFP reporter mice were used to test the colocalization of $\mathrm{CRF}_{1}$ and neurexins. The detailed step-by-step targeting procedure will be published in Science (Rejofo et al., 2011) or is available upon request (to J.M.D.). Briefly, the endogenous $\mathrm{Crf}_{1}$ locus was modified via homologous recombination in embryonic stem cells. Gene targeting resulted in a $\mathrm{Crf}_{1}$ knock-in allele where EGFP is inserted in frame into exon 2 of the $\mathrm{Crf}_{1}$ gene; concomitantly a selection cassette was introduced into intron 2 harboring a strong splice acceptor. In this configuration, exon 2 is spliced to the selection cassette, resulting in a $\mathrm{Crf}_{1}$ EGFP reporter allele which is at the same time a $\mathrm{Crf}_{1}$-null allele due to an immediate stop codon.

All animals were housed under a $12 \mathrm{~h} \mathrm{light/dark} \mathrm{cycle} \mathrm{(lights} \mathrm{on} \mathrm{at} \mathrm{6:00}$ A.M.) and constant temperature $\left(22 \pm 1^{\circ} \mathrm{C}\right)$ conditions with ad libitum access to both food and water. At 7-8 months of age, all mice were killed. The experiments were performed in accordance with European Communities Council Directive 2010/63/EU. The protocols were approved by the committee for the Care and Use of Laboratory Animals of the Government of Upper Bavaria, Germany.

Early-life stress procedure. The limited nesting and bedding material paradigm was performed as described previously (Rice et al., 2008). Two successive cohorts of dams were used. Briefly, the day of birth was designated postnatal day $0(\mathrm{P} 0)$. On the morning of $\mathrm{P} 2$, litters were culled to 6-8 pups, keeping at least one female and as many male pups as possible. Control dams ( $n=5$ and $n=10$ for each cohort) were provided with sufficient amount of nesting material ( 2 squares of Nestlets, Indulab) and standard sawdust bedding. In the "stress" cages, dams ( $n=5$ and $n=9$ for each cohort) were provided with limited quantity of nesting material (1/2 square of Nestlets), which was placed on a fine-gauge aluminum mesh platform (McNichols). All litters remained undisturbed during P2-P9. On P9, all dams were provided with standard nesting and bedding material. Male offspring were weaned on P28 and group housed in 4-5 per cage. Tail tips were collected and genotyped upon weaning when appropriate. At 5 months of age, all mice were single housed.

Behavioral and cognitive testing. To assess the effects of early-life stress on spatial learning and memory in wild-type and $\mathrm{CRF}_{1}$-CKO mice, two successive batches of mice (control wild-type, $n=20$; control $\mathrm{CRF}_{1}$ CKO, $n=17$; stressed wild-type, $n=18$; stressed $\mathrm{CRF}_{1}$-CKO, $n=10$ ) were tested under the same conditions and results were pooled. To assess the effects of postnatal forebrain CRF overexpression on spatial learning and memory, wild-type and CRF-COE mice (both $n=13$ ) were used, and only one wild-type and one CRF-COE mice were selected from each litter. Mice were tested at 6 months of age, and the tests were always performed between 8:00 A.M. and 12:00 noon and scored by the ANYmaze software (ANY-maze 4.50, Stoelting).

Y-maze. The Y-maze apparatus was made of gray polyvinyl chloride with three symmetrical arms $\left(30 \times 10 \times 15 \mathrm{~cm}^{3}\right)$ marked by triangle-, bar- and plus-signs, respectively, as intra-maze spatial cues, and was evenly illuminated (30 lux) (Sterlemann et al., 2010). Prominent extramaze spatial cues were attached to the walls at a distance of $\sim 25 \mathrm{~cm}$ from the apparatus. During the first trial (acquisition phase; $10 \mathrm{~min}$ ), the mice were allowed to explore two of the three arms with the third arm blocked. After a 30 min intertrial interval, the mice were placed in the center of the Y-maze and allowed to explore all arms freely (retrieval phase; $5 \mathrm{~min}$ ). An arm entry was counted when all four limbs of the mouse were within an $\mathrm{arm}$. The percentage of time spent in the novel arm and the two familiar arms was calculated, with a higher preference for the novel arm being rated as intact spatial recognition memory. Four mice (3 CRF-COE and 1 wild-type control) jumped out of the apparatus during the test and were therefore excluded from analysis.

Morris water maze. At $1 \mathrm{~d}$ after the Y-maze test, the Morris water maze test was performed as described previously (Sterlemann et al., 2010). A circular tank ( $110 \mathrm{~cm}$ in diameter) was filled with opaque colored water $\left(22 \pm 1^{\circ} \mathrm{C}\right)$, and prominent extra-maze visual cues were attached to the walls at a distance of $\sim 50 \mathrm{~cm}$ from the pool. After day 1 with a $60 \mathrm{~s}$ free swim trial, mice were trained to locate a visible platform $(10 \mathrm{~cm}$ in diameter) above the surface of the water for 4 trials (visual training). In the following spatial training sessions, mice received 4 trials per day to locate the submerged platform in a fixed position over 3 consecutive days. The order of starting locations was varied throughout trials. Next day, the reference memory was assessed in a 60 s probe trial with platform removed, and the latency to reach the platform area and the time spent in each quadrant were calculated. After $4 \mathrm{~d}$ of rest, mice received 4 trials to locate the hidden platform placed in the quadrant opposite to that in the spatial training sessions (reversal learning). The trials in visual, spatial and reversal training sessions were terminated once the mouse found the platform or $60 \mathrm{~s}$ had elapsed, and the latency to reach the platform was recorded for each trial. The intertrial interval was 10 min. Four mice ( 1 control wild-type and 3 control CRF $_{1}-\mathrm{CKO}$ ) that did not employ a search strategy and floated in the tank in all trials were excluded from analysis.

Brain slice preparation and electrophysiological recordings. Test-naive mice (control wild-type, $n=5$; control $\mathrm{CRF}_{1}$-CKO, $n=4$; stressed wild-type, $n=5$; stressed $\mathrm{CRF}_{1}-\mathrm{CKO}, n=6$; each mouse was selected from a different litter in each group) of 7-8 months old were anesthetized with isoflurane and decapitated, and brains were quickly removed. Brain slices were prepared using a vibrating microtome in ice-cold Ringer solution (containing, in mм: $124 \mathrm{NaCl}, 3 \mathrm{KCl}, 26 \mathrm{NaHCO}_{3}, 2$ $\mathrm{CaCl}_{2}, 1 \mathrm{MgSO}_{4}, 10$ D-glucose, and $1.25 \mathrm{NaH}_{2} \mathrm{PO}_{4}, \mathrm{pH} 7.3$ ) bubbled with a $95 \% \mathrm{O}_{2}-5 \% \mathrm{CO}_{2}$ mixture. All slices were placed in a holding chamber for at least $60 \mathrm{~min}$ and were then transferred to a superfusing chamber for extracellular recordings. The flow rate of the solution through the chamber was $1.5 \mathrm{ml} / \mathrm{min}$. Extracellular recordings were made using glass microelectrodes (2-3 M $\Omega$ ) filled with bath solution. All experiments were performed at room temperature (RT).

Field EPSPs (fEPSPs) at synapses between mossy fibers and CA3 pyramidal neurons or Schaffer collateral-commissural pathway (SCCP) and CA1 pyramidal cells were recorded extracellularly in the stratum lucidum of the CA3 or the stratum radiatum of CA1 and evoked by test stimuli $(0.066 \mathrm{~Hz}, 4-5 \mathrm{~V}, 20 \mathrm{~ms})$ delivered via a bipolar tungsten electrode insulated to the tip (50 $\mu \mathrm{m}$ in diameter) placed in either the granule cell layer of dentate gyrus (DG) or SCCP, respectively. High-frequency stimulation (HFS) of $3 \times 100 \mathrm{~Hz} / 100$ pulses with $10 \mathrm{~s}$ interstimulus intervals to mossy fibers or $1 \times 100 \mathrm{~Hz} / 100$ pulses to the SCCP were delivered to induce LTP. 
The recordings were amplified, filtered $(3 \mathrm{kHz})$ and digitized $(9 \mathrm{kHz})$ using a laboratory interface board (ITC-16, Instrutech), and stored with the acquisition program Pulse, version 8.5 (Heka Electronik). Data were analyzed offline with the analysis program IgorPro v.6 (WaveMetrics) software. Measurements of the amplitude of the fEPSP were taken and normalized with respect to the $30 \mathrm{~min}$ control period before tetanic stimulation.

Golgi impregnation and the analysis of spine density. Test-naive mice ( $n=4$ per group; each mouse was selected from a different litter in each group) of 7 months old were anesthetized with sodium pentobarbital $(200 \mathrm{mg} / \mathrm{kg}$, intraperitoneally) and transcardially perfused with $0.9 \%$ saline/heparin followed by $3 \%$ paraformaldehyde containing $0.5 \%$ glutaraldehyde in $0.1 \mathrm{~m}$ phosphate buffer $(\mathrm{PB}, \mathrm{pH} 7.4)$. The brains were stored in the same fixative overnight. Coronal sections (100 $\mu \mathrm{m}$ thick) from the dorsal hippocampus were cut on a vibrating microtome (VT1000, Leica) and washed. Sections were equilibrated in $0.1 \mathrm{M} \mathrm{PB}$, postfixed in $1 \%$ osmium tetroxide in $0.1 \mathrm{M} \mathrm{PB}$ for $30 \mathrm{~min}$, and further washed before trimming with a razor blade to maximize the diffusion of Golgi labeling solutions. The single-section Golgi-impregnation technique was performed as previously described (Gabbott and Somogyi, 1984). Areas where apical dendrites of Golgi-impregnated neurons were examined included the stratum radiatum of area CA3 and CA1 and the middle molecular layer of DG.

Spines were counted using Neurolucida software (MicroBrightField) on a Nikon $80 \mathrm{i}$ microscope equipped with a $100 \times, 1.25$ numerical aperture oil-immersion lens. For each area examined, 10 segments of dendrites of similar diameter and a length of $>30 \mu \mathrm{m}$ were chosen. Spine density was calculated as the number of spines per $1 \mu \mathrm{m}$ of dendrite segment.

In situ hybridization. Mice that underwent the Y-maze and the Morris water maze tests were selected to examine the expression levels of the genes and proteins of interest in the hippocampus. At 1 week after the behavioral tests, mice (control wild-type, $n=11$; control $\mathrm{CRF}_{1}-\mathrm{CKO}$, $n=7$; stressed wild-type, $n=8$; stressed $\mathrm{CRF}_{1}-\mathrm{CKO}, n=7$ ) of 7 months old were anesthetized with isoflurane and killed. Brains were removed, snap-frozen and sectioned coronally at $16 \mu \mathrm{m}$ through the dorsal hippocampus (bregma -1.58 to -2.18 ) (Paxinos and Watson, 2001) at $-20^{\circ} \mathrm{C}$ in a cryotome (Microm HM 560, Thermo Fisher Scientific). The sections were thaw-mounted on Superfrost slides, dried, and kept at $-80^{\circ} \mathrm{C}$. In situ hybridization using $\left[{ }^{35} \mathrm{~S}\right] \mathrm{UTP}$-labeled ribonucleotide probes was performed as previously described (Schmidt et al., 2007). The following primers were used to generate antisense RNA hybridization probes that recognize neurexin-1 (469 base pairs), neuroligin-1 (461 base pairs), neuroligin-2 (401 base pairs), and neuroligin-3 (511 base pairs), respectively: (1) neurexin-1, AGTTGTACCTGGGTGGCTTG (forward primer) and TCACACGTCCTGCATCTAGC (reverse primer); (2) neuroligin-1, GGGGATGAGGTTCCCTATGT (forward primer) and GG ATCATCCTGTTTGGCAGT (reverse primer); (3) neuroligin-2, TGTGTG GTTCACCGACAACT (forward primer) and CTCCAAAGTGGGCAATGT TT (reverse primer); (4) neuroligin-3, CCATCATCCAAAGTGGCTCT (forward primer) and TCAGTGAAGAGTGCCACCAG (reverse primer). The slides were apposed to Kodak Biomax MR films and developed. Autoradiographs were digitized, and relative expression was determined by computer-assisted optical densitometry (Scion).

Double-fluorescence immunohistochemistry, image acquisition, and quantification. At 1 week after the behavioral tests, mice (control wildtype, $n=4$; control $\mathrm{CRF}_{1}$-CKO, $n=3$; stressed wild-type, $n=4$; stressed $\mathrm{CRF}_{1}-\mathrm{CKO}, n=3$; each mouse was selected from a different litter in each group) of 7 months old were anesthetized with sodium pentobarbital and transcardially perfused with $0.9 \%$ saline/heparin followed by $4 \%$ buffered paraformaldehyde. Double-labeling immunofluorescence was performed on free-floating coronal sections ( $25 \mu \mathrm{m}$ thick) obtained from postfixed and cryoprotected brains as described previously (Chen et al., 2004a). The following primary antibodies were used: goat anti-EGFP (1:2000, Abcam), mouse anti-vesicular glutamate transporter 1 (VGLUT1; 1:1000, Synaptic Systems), goat antivesicular GABA transporter (VGAT; 1:1000, Synaptic Systems), and rabbit anti-neurexins (detects most isoforms and corresponding splicevariants of neurexins; 1:500, Synaptic Systems). After incubation with primary antibodies diluted in $1 \%$ donkey serum and $0.3 \%$ Triton X-100 in $0.1 \mathrm{M} \mathrm{PB}$ at $4^{\circ} \mathrm{C}$ for $40 \mathrm{~h}$, sections were rinsed and incubated with Alexa Fluor 488- or 647-conjugated donkey secondary antibodies (1:500, Invitrogen) for $2 \mathrm{~h}$ at RT. After rinsing, sections were transferred onto slides, dried, and coverslipped with Vectashield containing 4',6diamidino-2-phenylindole (Vector Laboratories).

Fluorescent images $(1600 \times 1600$ pixels $)$ were obtained with an Olympus IX81 confocal microscope and a $40 \times$ water-immersion objective (Olympus) using the Kalman filter and sequential scanning mode under identical settings for laser power, photomultiplier gain and offset. For the colocalization assessment of $\mathrm{CRF}_{1}$ and neurexins, images were adjusted for better brightness and contrast using the FV10-ASW 1.7 software (Olympus). For the comparison of fluorescent signals among groups, images were imported into the NIH ImageJ software, converted to 8-bit grayscale, and thresholded uniformly. The density of synaptic puncta was quantified using the "analyze particle" module of the ImageJ program.

Statistical analysis. For the analyses of spine density and VGLUT1- and VGAT-immunoreactive puncta density, data were normalized by taking the value of the control wild-type group as $100 \%$. Data were analyzed by two-way ANOVA followed by Bonferroni post hoc test as necessary. Three-way ANOVA with condition and genotype as between-subjects factors and trial as a within-subject factor was performed on the Morris water maze data of each spatial training day and the reversal learning day, followed by two-way ANOVA with either condition or genotype as a between-subjects factor and trial as a within-subject factor when applicable. Student's $t$ test was used to compare pairs of means. The level of statistical significance was set at $p<0.05$. To evaluate the effects of condition, genotype, and condition $\times$ genotype interaction, the level of statistical significance was set at $p<0.05$ for main effects and $p<0.1$ for interactions. Data are expressed as mean \pm SEM.

\section{Results}

\section{Forebrain $\mathrm{CRF}_{1}$ signaling mediates early-life stress-impaired spatial learning and memory}

It has been suggested that hippocampus-dependent learning and memory is selectively impaired by early-life stress in middle-aged but not young rats (Brunson et al., 2005). Therefore, all mice were tested at 6 months of age. Spatial memory in adult wild-type and $\mathrm{CRF}_{1}$-CKO mice was first evaluated by the $\mathrm{Y}$-maze test (Fig. $1 A$ ). A significant main effect of stress $\left(F_{(1,61)}=4.482, p<0.05\right)$ on time spent in the novel arm was observed. Post hoc analysis showed that stressed wild-type mice, while able to discriminate the novel arm from the familiar, performed significantly worse than wild-type controls ( $p<0.05$, Bonferroni's test). In contrast, the performance of stressed $\mathrm{CRF}_{1}-\mathrm{CKO}$ mice was similar to that of the controls. Importantly, similar results were obtained by using the number of the litters as experimental $\mathrm{N}$ per group (twoway ANOVA of condition, $F_{(1,33)}=5.790, p<0.05$; and $p<0.05$ for control versus stressed wild-type mice, Bonferroni's test).

To further assess spatial learning and memory, mice were tested in the Morris water maze task (Fig. $1 B$ ). On the first day of spatial training, a significant stress $\times$ genotype interaction (three-way ANOVA, $F_{(1,57)}=4.028, p<0.05$ ) effect on escape latency was noticed. Spatial acquisition was hampered by earlylife stress in wild-type mice, as shown by a significant increase in the latency to locate the hidden platform compared with the controls (two-way ANOVA of condition, $F_{(1,35)}=6.622, p<0.05$ ). This impairment was mostly evident in the third trial $(p<0.01$, unpaired $t$ test). In contrast, stressed $\mathrm{CRF}_{1}$-CKO mice spent similar time to reach the platform compared with the controls. Similar findings were revealed by using the number of the litters as experimental $N$ (two-way ANOVA of interaction, $F_{(1,31)}=3.233$, $p<0.1$; and $p<0.05$ for control versus stressed wild-type mice, Bonferroni's test). Notably, impaired spatial learning in stressed wild-type mice was not due to swimming ability or motivation as shown by similar swim speed to the controls (data not shown). 

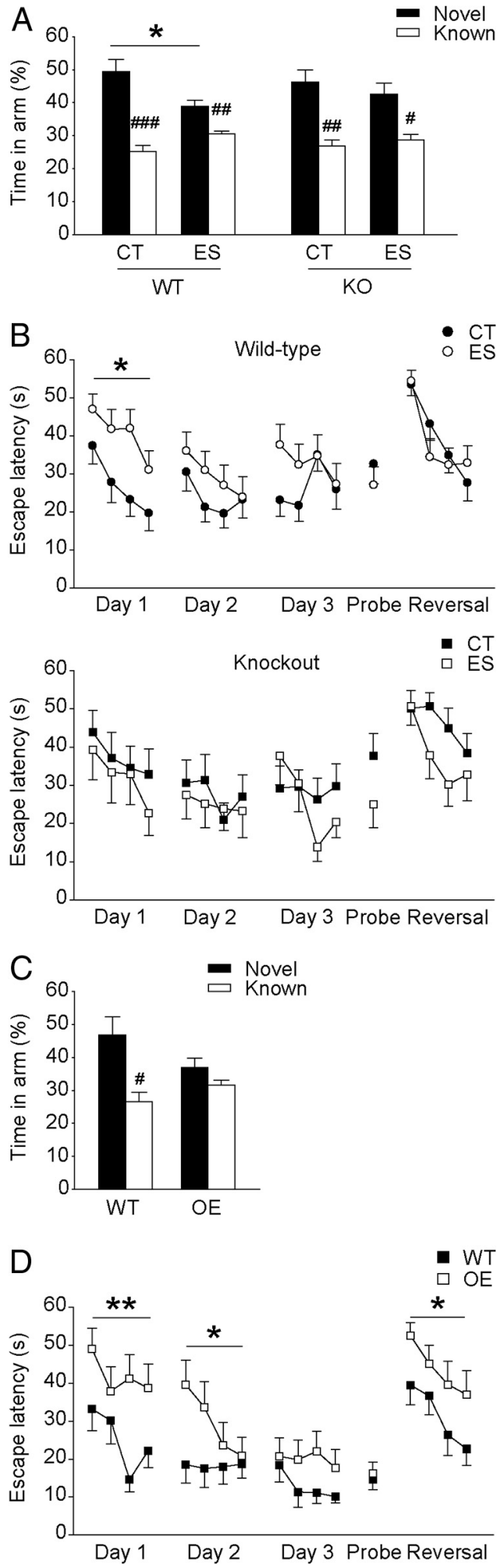

Figure 1. $A, B$, Spatial learning and memory in adult wild-type and $\mathrm{CRF}_{1}-\mathrm{CKO}_{\mathrm{O}}$ mice that were exposed to either control condition or early-life stress. $\boldsymbol{A}$, In the Y-maze test, all groups of animals spent more time exploring the novel arm versus the known ones. However, stressed wild-type mice performed significantly worse than wild-type controls, while stressed CRF $F_{1}$-CKO mice displayed performance comparable to that of the controls. $\boldsymbol{B}$, In the Morris water maze test, stressed wild-type mice took significantly longer to locate the hidden platform in the first spatial training day, indicating impaired acquisition of spatial information. In contrast, stressed $\mathrm{CRF}_{1}$-CKO mice spent similar time to reach the platform compared with the controls. $C_{,} \boldsymbol{D}$, Spatial learning and memory in adult wild-type and CRF-COE mice. $\boldsymbol{C}$, In the Y-maze test, wild-type mice showed preference to the novel arm, whereas CRF-COE mice visited the novel
Animals from all groups acquired the task similarly on the following $2 \mathrm{~d}$. In addition, no difference was observed among groups in the retention of spatial information (probe trial, data not shown) and cognitive flexibility (reversal learning).

Next, we evaluated the cognitive performance of conditional forebrain CRF-overexpressing mice, whose forebrain CRF$\mathrm{CRF}_{1} / \mathrm{CRF}_{2}$ signaling is persistently augmented. In the $\mathrm{Y}$-maze task (Fig. 1C), wild-type but not CRF-COE mice distinguished the novel arm from the familiar ones ( $p<0.05$, paired $t$ test). In the Morris water maze task (Fig. 1D), the performance of CRFCOE mice was significantly poorer in the first $2 \mathrm{~d}$ of spatial training $\left(F_{(1,24)}=11.043, p<0.01\right.$, and $F_{(1,24)}=4.709, p<0.05$, respectively) and the reversal learning session $\left(F_{(1,24)}=5.302\right.$, $p<0.05)$ compared with wild-type mice. No differences in swimming ability or reference memory were found between groups (data not shown).

Together, these data suggest that stressful early-life experience attenuates hippocampus-dependent learning and memory in adulthood, and that this effect is largely dependent on forebrain $\mathrm{CRF}_{1}$ signaling. To investigate the mechanisms underlying forebrain $\mathrm{CRF}_{1}$-modulated cognitive impairments induced by earlylife stress, only $\mathrm{CRF}_{1}-\mathrm{CKO}$ mice and corresponding wild-type mice were used in the following experiments.

Forebrain $\mathrm{CRF}_{1}$ inactivation abolishes the impairment of $\mathrm{CA} 3$ LTP and enhances CA1 LTP in early-life-stressed mice

LTP is considered a major cellular correlate for learning and memory (Lynch, 2004). In the rat it was previously shown that early-life stress impaired hippocampal LTP (Brunson et al., 2005) in a $\mathrm{CRF}_{1}$-dependent manner (Ivy et al., 2010). To assess whether impaired spatial memory in stressed wild-type mice is associated with altered synaptic plasticity in hippocampal circuits, we examined both mossy fiber-CA3 LTP and SCCP-CA1 LTP in acute brain slices (Fig. 2). A significant condition $\times$ genotype interaction $\left(F_{(1,24)}=4.648, p<0.05\right)$ effect on mossy fiber-CA3 LTP was revealed. In the final $10 \mathrm{~min}$, LTP was significantly impaired in stressed wild-type mice compared with the controls $(p<0.05$, Bonferroni's test). LTP deficits seen in stressed wild-type mice were prevented by forebrain $\mathrm{CRF}_{1}$ deficiency, as indicated by similarly prominent LTP in hippocampal CA3 neurons in both control and stressed $\mathrm{CRF}_{1}$-CKO mice (Fig. $2 \mathrm{~A}$ ). In the CA1 region, a significant interaction effect $\left(F_{(1,30)}=8.457, p<0.01\right)$ and a main effect of genotype $\left(F_{(1,30)}=12.850, p<0.01\right)$ on LTP were observed. Unlike findings in middle-aged rats (Brunson et al., 2005; Ivy et al., 2010), fEPSP potentiation was similar in control and stressed wild-type mice, whereas HFS-induced LTP was surprisingly augmented in stressed $\mathrm{CRF}_{1}-\mathrm{CKO}$ mice compared with control and stressed counterparts $(p<0.05$ and $p<0.001$ respectively, Bonferroni's test; Fig. $2 B$ ). These results point to the possibility that $\mathrm{CRF}_{1}$ inactivation may overcompensate disrupted synaptic function in specific neuronal networks induced by earlylife stress.

\section{Forebrain $\mathrm{CRF}_{1}$ deficiency attenuates structural alterations} Evoked by early-life stress

Stress-induced structural modifications such as dendritic atrophy (Brunson et al., 2005; Ivy et al., 2010) and loss of dendritic

and familiar arms similarly. $\boldsymbol{D}$, In the Morris water maze test, CRF-COE mice exhibited profound spatial learning impairments in the first two spatial training days and reduced cognitive flexibility in the reversal learning session. $C T$, Control; $E S$, early-life stress; $K 0, C R F_{1}-C K O ; O E$, CRFCOE. ${ }^{*} p<0.05,{ }^{* *} p<0.01$ versus control wild-type group. ${ }^{\#} p<0.05$, ${ }^{\# \#} p<0.01,{ }^{\# \#} p<$ 0.001 versus respective novel arm. $n=10-20$ mice per group. 

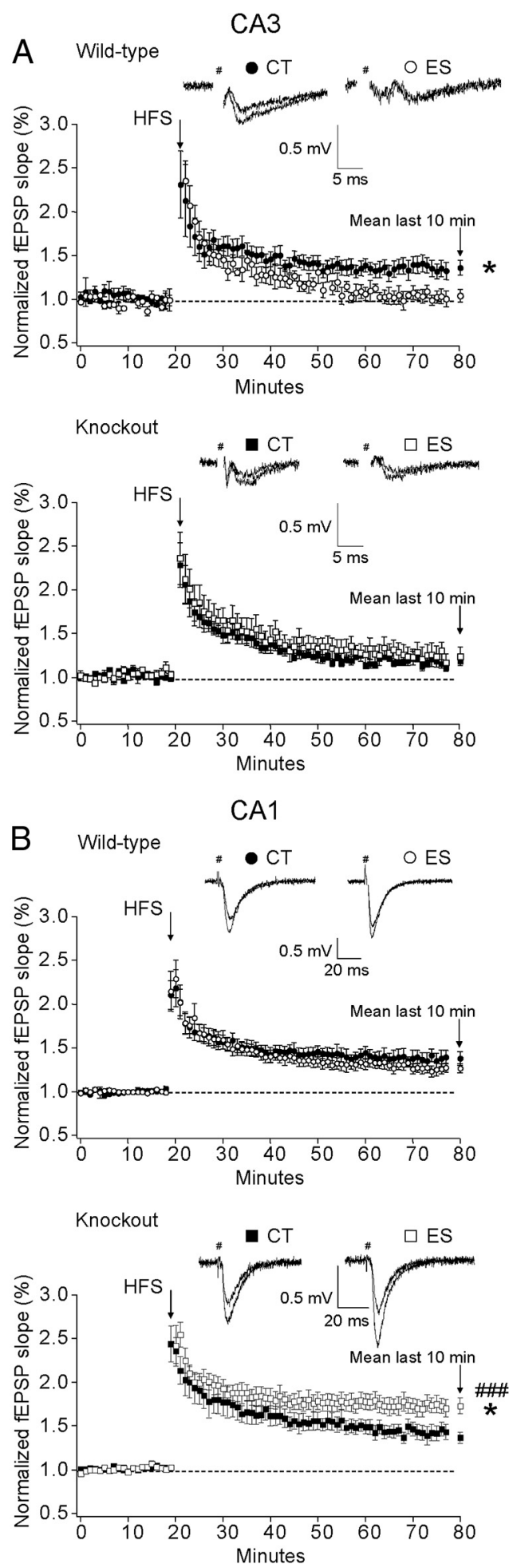

Figure 2. $\quad \boldsymbol{A}, \boldsymbol{B}$, Effects of early-life stress on mossy fiber-CA3 LTP $(\boldsymbol{A})$ and SCCP-CA1 LTP $(\boldsymbol{B})$ in adult wild-type and CRF $_{1}$-CKO mice. Representative traces for control and LTP are shown. $A$, After a HFS was delivered, mossy fiber-CA3 LTP was absent in stressed wild-type mice as indicated by significantly reduced amplitude of fEPSP in the last $10 \mathrm{~min}$ compared with wild-type controls. In contrast, CRF 1 -CKO mice showed intermediate LTP. $B$, In the CA1 region, no difference in fEPSP potentiation was noticed between control and stressed wild-type mice, whereas LTP was surprisingly enhanced in the slices of stressed CRF $_{1}$-CKO mice. CT, Control; ES, early-life stress. ${ }^{*} p<0.05$ versus the control group. ${ }^{\# \#} p<0.001$ versus stressed wild-type group. $n=$ $4-6$ mice per group. spines (Chen et al., 2008) are associated with impaired synaptic plasticity and memory. We therefore measured apical dendritic spine density in CA3 and CA1 pyramidal neurons in wild-type and $\mathrm{CRF}_{1}$-CKO mice (Fig. 3). In the stratum radiatum of area CA3, a significant effect of interaction $\left(F_{(1,12)}=29.700, p<\right.$ 0.001 ) on spine density was revealed (Fig. $3 A, B$ ). Stressed wildtype mice had fewer dendritic spines in CA3 stratum radiatum than the controls and stressed $\mathrm{CRF}_{1}-\mathrm{CKO}$ mice (both $p<0.01$, Bonferroni's test). The density of mature, Golgi-impregnated spines was lower in control $\mathrm{CRF}_{1}$-CKO mice compared with control wild-type mice, and this was reversed by early-life stress (both $p<0.01$, Bonferroni's test). In the stratum radiatum of area CA1, early-life stress did not influence spine density in wild-type mice. We found a significant effect of interaction $\left(F_{(1,12)}=11.200, p<\right.$ $0.01)$ and a main effect of stress $\left(F_{(1,12)}=17.920, p<0.01\right)$ on spine density (Fig. $3 C, D$ ). Specifically, stressed $C F_{1}-C K O$ mice had higher spine density than control $\mathrm{CRF}_{1}-\mathrm{CKO}$ and stressed wild-type mice $(p<0.001$ and $p<0.05$ respectively, Bonferroni's test). Notably, spine density in the middle molecular layer of DG and cell density of the hippocampus were similar among groups (data not shown).

Early-life stress interacts with forebrain $\mathrm{CRF}_{1}$ to modulate excitatory and inhibitory synaptic networks in the hippocampus

To further investigate whether synaptic density in the apical dendritic region of hippocampal CA 3 and CA1 is influenced by earlylife stress and forebrain $\mathrm{CRF}_{1}$ inactivation, VGLUT1 and VGAT were immunostained as markers for excitatory and inhibitory synaptic terminals, respectively (Fig. 4). Two-way ANOVA revealed significant effects of interaction $\left(F_{(1,10)}=5.593, p<0.05\right)$ and stress $\left(F_{(1,10)}=8.091, p<0.05\right)$ on the number of VGLUT1positive puncta in the stratum radiatum of CA3. As indicated by VGLUT1 immunostaining, there was no difference in excitatory synaptic density between control wild-type and control $\mathrm{CRF}_{1}$-CKO mice. The number of excitatory synapses was significantly reduced in stressed wild-type $(p<0.01$ versus wild-type controls, Bonferroni's test) but not stressed $\mathrm{CRF}_{1}$ CKO mice (Fig. $4 A, C$ ), while inhibitory synaptic density as shown by VGAT immunostaining in area CA3 remained unchanged among groups (Fig. $4 B$ ). In the stratum radiatum of area CA1, a significant effect of interaction $\left(F_{(1,10)}=5.427\right.$, $p<0.05)$ on VGLUT1 puncta density and a significant main effect of stress $\left(F_{(1,10)}=22.950, p<0.001\right)$ on VGAT puncta density were observed. The number of VGLUT1-positive puncta was reduced in stressed wild-type ( $p<0.05$ versus wild-type controls, Bonferroni's test) but not stressed $\mathrm{CRF}_{1}$ CKO mice, whereas VGAT-immunoreactive puncta density was significantly decreased by early-life stress in both wildtype and $\mathrm{CRF}_{1}$-CKO mice $(p<0.01$ and $p<0.05$ respectively, Bonferroni's test; Fig. $4 D-F$ ). Together with the electrophysiological and morphological data, these findings suggest that early-life stress interacts with forebrain $\mathrm{CRF}_{1}$ to differentially regulate synaptic transmission and plasticity in CA3 and CA1.

\section{Hippocampal neurexin-1 and neuroligin-3 are differentially} altered by early-life stress and forebrain $\mathrm{CRF}_{1}$

The trans-synaptic cell adhesion molecules neurexins and neuroligins specify synaptic function of excitatory and inhibitory networks, and are implicated in synaptic plasticity and cognitive function (Südhof, 2008). Therefore, we evaluated gene expression levels of hippocampal neurexins and neuroligins in wildtype and $\mathrm{CRF}_{1}$-CKO mice (Fig. 5). A significant main effect of 

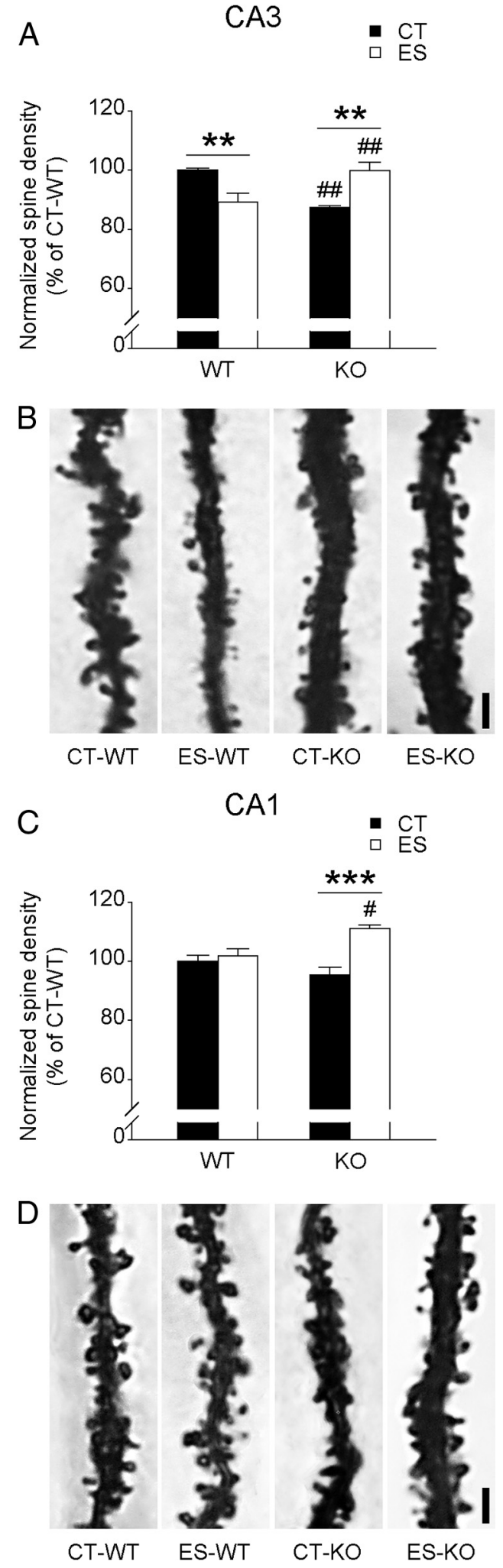

Figure 3. Effects of early-life stress on apical dendritic spine density in the stratum radiatum of $\mathrm{C} A 3$ and $\mathrm{C} A 1$ in adult wild-type and $\mathrm{CRF}_{1}$ - $\mathrm{CK} 0$ mice. $A$, In the $\mathrm{CA} 3$ region, spine density was reduced in stressed wild-type and control $\mathrm{CRF}_{1}-\mathrm{CKO}$ mice, whereas stressed $\mathrm{CRF}_{1}$-CKO mice had more spines than control and stressed counterparts. $\boldsymbol{B}$, Representative photomicrographs showing the apical dendrites and spines of Golgi-impregnated $\mathrm{CA}_{3}$ pyramidal neurons. $C$, In the $C A 1$ region, stressed $\mathrm{CRF}_{1}-\mathrm{CKO}$ mice had more exuberant spines than the control $\mathrm{CRF}_{1}$-CKO and stressed wild-type groups. $\boldsymbol{D}$, Representative photomicrographs showing the apical dendrites and spines of Golgi-impregnated CA1 pyramidal neurons. $\mathrm{CT}$, Control; $\mathrm{ES}$, early-life stress; $\mathrm{KO}, \mathrm{CRF}_{1}$-CKO. Scale bars, $2 \mu \mathrm{m} .{ }^{* *} p<0.01$, stress $\left(F_{(1,29)}=4.429, p<0.05\right)$ on CA3 neurexin-1 mRNA levels was revealed (Fig. $5 A, B$ ). Compared with the controls, stressed wild-type but not $\mathrm{CRF}_{1}$-CKO mice showed a significant decrease in neurexin- 1 mRNA levels ( $p<0.05$, Bonferroni's test). Moreover, the mRNA levels of neuroligin- 3 were reduced in CA1 by early-life stress (two-way ANOVA of condition, $F_{(1,27)}=14.360$, $p<0.001$ ) in both wild-type and $\mathrm{CRF}_{1}$-CKO mice (both $p<$ 0.05, Bonferroni's test; Fig. 5C,D). Neuroligin-3 gene expression was also affected by stress in CA3 (two-way ANOVA of condition, $F_{(1,27)}=8.634, p<0.01$ ) and DG (two-way ANOVA of condition, $\left.F_{(1,27)}=12.420, p<0.01\right)$. Post hoc test revealed that neuroligin-3 mRNA levels were significantly reduced in the DG of stressed wild-type mice ( $p<0.05$ versus wild-type controls, Bonferroni's test). In contrast, the gene expression levels of neurexin-1 in CA1 and DG and neuroligin-1 and neuroligin-2 in all hippocampal subregions remained unaltered among groups (data not shown).

Additionally, we found that $\mathrm{CRF}_{1}$ was in close proximity with neurexins in specific subcellular compartments of hippocampal pyramidal neurons (Fig. 5E). This partial colocalization was prominent in neuronal soma and dendrites, suggestive of potential functional interactions between $\mathrm{CRF}_{1}$ and neurexins.

\section{Discussion}

In this study, we demonstrate that early-life stress impairs hippocampus-dependent spatial learning and memory in adult mice, and is associated with physiological, morphological and molecular abnormalities in the hippocampus. Impairments of spatial learning and memory by early-life stress are recapitulated by forebrain $\mathrm{CRF}$ overexpression and attenuated by forebrain $\mathrm{CRF}_{1}$ inactivation, suggesting that forebrain $\mathrm{CRF}_{1}$ is crucial for the programming of cognitive function by early-life stress.

\section{Early-life stress-induced late-onset cognitive deficits,} forebrain $\mathrm{CRF}_{1}$, and glucocorticoids

Early experiences shape brain development and cognitive function (Korosi and Baram, 2009; Lupien et al., 2009). In rodents, exposure to an impoverished postnatal environment, which disrupts maternal behavior and mother-pup interaction, impairs hippocampal integrity and cognition of adult offspring (Fenoglio et al., 2006). Consistent with findings using the same stress paradigm (Rice et al., 2008), adult stressed wild-type mice exhibited impaired performance in spatial tasks. Intriguingly, the cognitive impairments in stressed animals were abolished by forebrain $\mathrm{CRF}_{1}$ inactivation, extending the findings using postnatal treatment of a selective $\mathrm{CRF}_{1}$ antagonist (NBI-30775) (Ivy et al., 2010). These data suggest that the interactions between environmental risk factors and genetic predispositions are decisive in sculpting brain function and the expression of psychopathology (Charney and Manji, 2004; Schmidt, 2010).

The involvement of CRF and $\mathrm{CRF}_{1}$ in stress-induced cognitive decline has been investigated in previous studies. Transgenic CRF overexpression (Heinrichs et al., 1996) or postnatal CRF administration (Brunson et al., 2001) impaired spatial learning and memory in adult rodents, whereas postnatal administration of NBI-30775 prevented these effects (Ivy et al., 2010) and improved spatial performance in adult rats (Fenoglio et al., 2005). However,

$\leftarrow$

${ }^{* * *} p<0.001$ versus the control group. ${ }^{\#} p<0.05,{ }^{\# \#} p<0.01$ versus the group under the same condition. $n=4$ mice per group. 

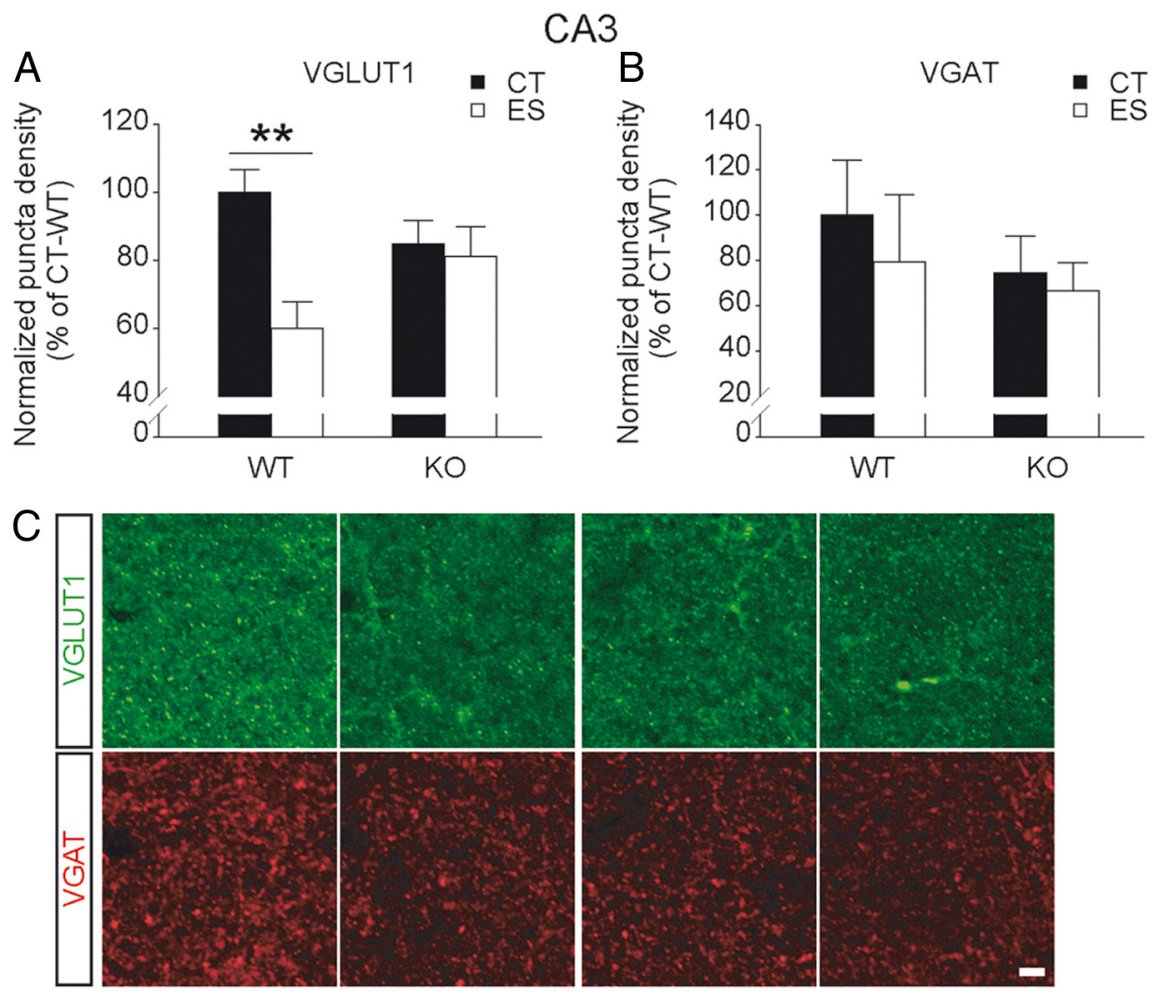

CT-WT

ES-WT

CA1
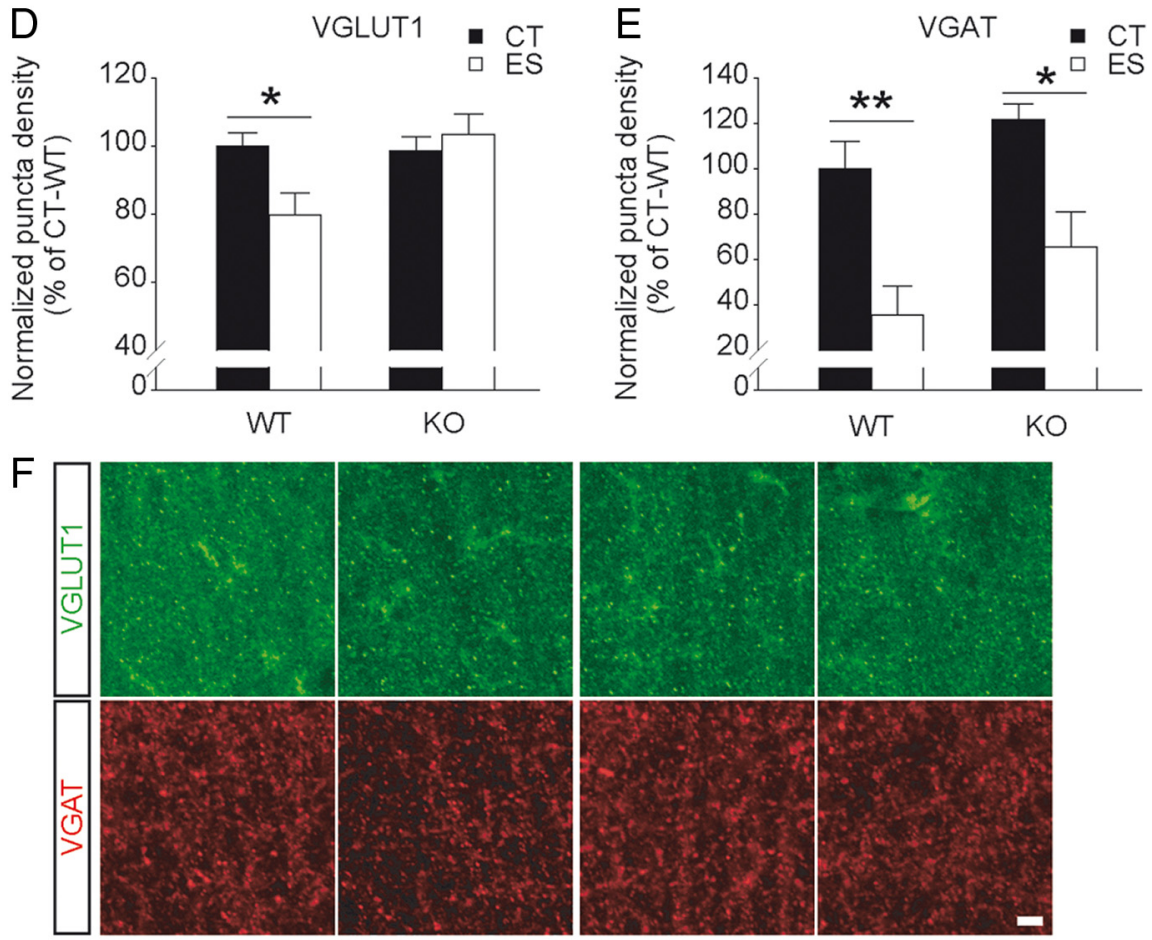

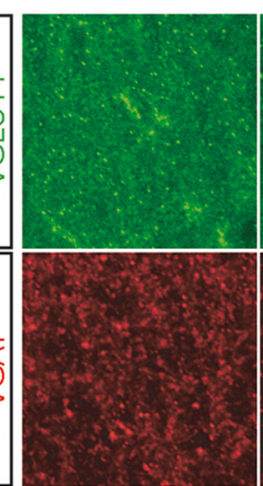

CT-WT
ES-WT

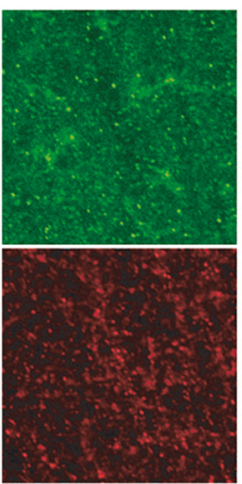

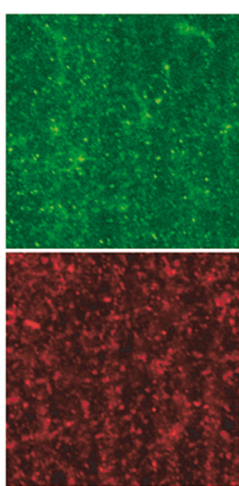

CT-KO

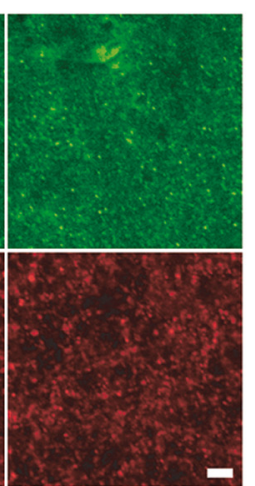

ES-KO
Figure 4. Effects of early-life stress on excitatory and inhibitory synaptic density in area CA3 and CA1 in adult wild-type and CRF -CKO $_{1}$ mice. $A$, The number of VGLUT1-positive synaptic puncta in CA3 stratum radiatum was significantly reduced in stressed wild-type but not stressed CRF 1 -CKO mice. $\boldsymbol{B}$, VGAT puncta density in area CA3 remained unchanged among groups. $\boldsymbol{C}$, Representative confocal images taken from the stratum radiatum of CA3a (alongside stratum lucidum) showing VGLUT1- and VGAT-immunoreactive synaptic puncta. D, The number of VGLUT1-positive puncta in CA1 stratum radiatum was also decreased in stressed wild-type but not stressed CRF ${ }_{1}$-CKO mice. $\boldsymbol{E}$, VGAT puncta density in area CA1 was reduced by early-life stress in both wild-type and CRF $F_{1}$-CKO mice. $F$, Representative confocal images taken from the stratum radiatum of CA1b (alongside stratum pyramidale) showing VGLUT1- and VGAT-immunoreactive synaptic puncta. $\mathrm{CT}$, Control; ES, early-lifestress; $\mathrm{KO}, \mathrm{CRF}_{1}$-CKO. Scalebars, $5 \mu \mathrm{m} .{ }^{*} p<0.05,{ }^{* *} p<0.01$ versus the control group. $n=3-4$ mice per group. these approaches manipulated multiple brain regions, thus leave the neuroanatomical sites of action unclear. We observed that forebrain CRF-overexpressing mice exhibited impaired spatial performance, mirroring the cognitive phenotype of stressed wild-type mice, while stressed $\mathrm{CRF}_{1}-\mathrm{CKO}$ mice performed similarly to the controls. These findings pinpoint the importance of forebrain $\mathrm{CRF}_{1}$ in modulating cognitive function after postnatal stress exposure.

Because the calcium/calmodulin kinase II $\alpha$-driven suppression of $\mathrm{CRF}_{1} \mathrm{did}$ not take place until the end of the second postnatal week (Wang et al., 2011), the deletion of the $\mathrm{Crf}_{1}$ gene in $\mathrm{CRF}_{1}-\mathrm{CKO}$ mice occurred after the epoch of early-life stress (P2-P9). Although these mice were likely capable of forebrain $\mathrm{CRF}_{1}$ signaling during the stress, its absence in the critical weeks after the stress protected them from structural and functional disturbances of the hippocampus. This indicates that following early-life stress is a window of opportunity where hippocampal plasticity is still present, and where intervention might rescue from the adverse effects of early-life stress (Ivy et al., 2010).

Glucocorticoids, acting via mineralocorticoid receptors (MRs) and glucocorticoid receptors (GRs), are other key stress mediators affected by early-life stress (Joëls and Baram, 2009). Glucocorticoid excess during postnatal stress exposure, the resultant disruption of glucocorticoid feedback and the imbalance between hippocampal MR and GR have been postulated as a leading molecular basis of stress-induced cognitive deficits (de Kloet et al., 1999; Joëls et al., 2006; Oitzl et al., 2010). However, neonatal dexamethasone (a synthetic glucocorticoid) treatment failed to consistently impair cognition in adult rats (Kamphuis et al., 2003; Lin et al., 2006). Recent evidence indicates that the alterations of hippocampal GR after early-life experience may be secondary to changes of $\mathrm{CRF}_{1}$ signaling in the paraventricular nucleus (Korosi and Baram, 2009; Korosi et al., 2010) and likely the hippocampus (Fenoglio et al., 2005), and may be paralleled with, instead of being causally related to, cognitive changes. In addition, basal corticosterone levels and stress response were unaltered by chronic stress in adult wild-type and $\mathrm{CRF}_{1}-\mathrm{CKO}$ mice (Wang et al., 2011) or by forebrain CRF overexpression (Lu et al., 2008). Therefore, our data support the hypothesis that abnormal hippocampal $\mathrm{CRF}_{1}$ signaling largely accounts for the cognitive deficits in adult mice experienced early adversities. 
Early-life stress-induced synaptic dysfunction and dendritic spine loss are attenuated by forebrain $\mathrm{CRF}_{1}$ inactivation

LTP, an activity-dependent enhancement of synaptic efficacy (Lynch, 2004), is disrupted in adult rodents by early-life stress in CA3 (Brunson et al., 2005), CA1 (Brunson et al., 2005; Champagne et al., 2008; Ivy et al., 2010) and DG (Bagot et al., 2009) in a $\mathrm{CRF}_{1}$-dependent manner (Ivy et al., 2010). Whereas the commissural/associational LTP was examined in rats, we also found disturbed mossy fiber-CA3 LTP in stressed wild-type mice. Moreover, LTP in SCCPCA1 synapses was normal in stressed wildtype mice, whereas deficits were observed in stressed rats. This disparity may arise from species/age differences and the sensitivity of the procedure, as there was a reduction in the number of excitatory synapses in CA1 in both species (dendritic atrophy in stressed rats and reduced VGLUT1 immunoreactivity in stressed mice). Interestingly, forebrain $\mathrm{CRF}_{1}$ inactivation not only abolished the effects of early-life adversity on CA3 LTP maintenance, but facilitated SCCP-CA1 LTP in stressed mice, indicating an important involvement of $\mathrm{CRF}_{1}$ signaling in both neural circuitries.

Acute stress initiates the release of CRF (Chen et al., 2004a) that promotes rapid loss of CA3 dendritic spines (Chen et al., 2008), which is dependent on $\mathrm{CRF}_{1}$ and correlates with cognitive defects and LTP attenuation (Chen et al., 2010); whereas recurrent exposure to high "stress levels" of CRF results in dendritic atrophy (Chen et al., 2004b). We found an overt reduction in CA3 spine density and the total number of excitatory synapses, coupled with attenuated CA3 LTP and spatial performance, in stressed wild-type but not stressed $\mathrm{CRF}_{1}$-CKO mice. In area CA1, however, more subtle loss of excitatory synapses took place in stressed wild-type mice. Because the relative number of spines on each dendrite remained unchanged in these animals, the loss of excitatory terminals in CA1 likely reflects the shrinkage of dendritic branches. Together with published data in rats (Brunson et al., 2005; Ivy et al., 2010), these results suggest that early-life stress may hamper the development of CA3 neurons, which in turn remodels structure and function in CA1.

We observed that forebrain $\mathrm{CRF}_{1}$ inactivation per se reduced spine density in the apical dendrites of CA3 pyramidal neurons, which was not apparent after early-life stress. Considering that cognition and synaptic plasticity in control $\mathrm{CRF}_{1}$-CKO mice remained intact, mechanisms such as increased complexity of CA3 proximal dendrites (Chen et al., 2004b) likely compensate these morphological changes. It should be noted that the predominant thin and filopodia-like spines observed in YFP-expressing $\mathrm{CRF}_{1}$ mutant mice (Chen et al., 2008) may be poorly impregnated by the Golgi method used here, resulting in a potential underestimation of the total number of spines in control $\mathrm{CRF}_{1}$-CKO mice.
CA3

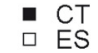

B
WT

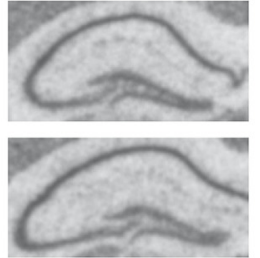

CT
Neurexin-1 mRNA

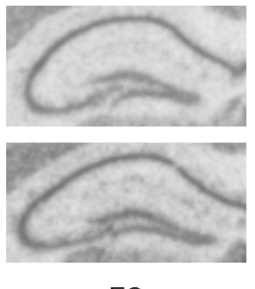

ES

D

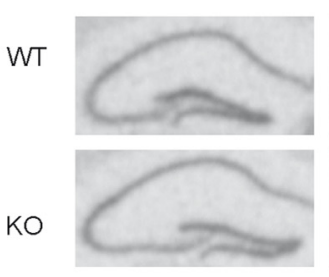

CT

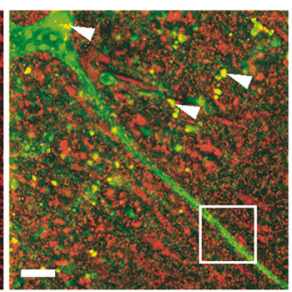

Merge

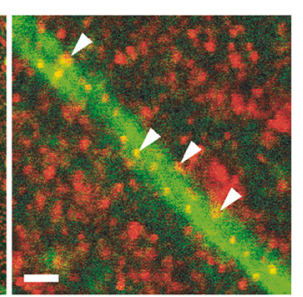

Inlay

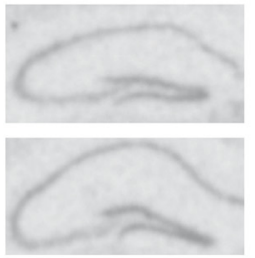

ES
Neurexins

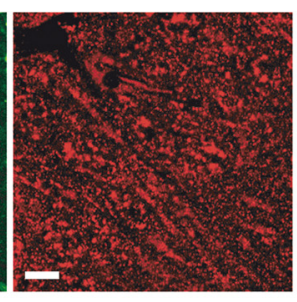

Figure 5. Effects of early-life stress on hippocampal neurexin-1 and neuroligin-3 gene expression in adult wild-type and terminals and dendrites of CA1 pyramidal neurons. Arrows indicate CRF $_{1}-$ EGFP and neurexins colocalized puncta. CT, Control; ES, early-life stress; KO, CRF - CKO. Scale bars: Left and middle two panels, $10 \mu \mathrm{m}$; right panel, $2 \mu \mathrm{m} .{ }^{*} p<0.05$ versus the control group. $n=6-11$ mice per group.

Moreover, stressed $\mathrm{CRF}_{1}-\mathrm{CKO}$ mice had more spines in CA1 neurons, which may account for enhanced SCCP-CA1 LTP.

In the hippocampus, excitatory synapses are found on dendritic spines whereas inhibitory synapses are primarily perisomatic. As $\mathrm{CRF}_{1}$ resides on spines (Chen et al., 2004a), it is not surprising that the major contribution of $\mathrm{CRF}_{1}$ to the effects of early-life stress involved more excitatory than inhibitory synapses. The modulation of excitatory and inhibitory network by the interaction between $\mathrm{CRF}_{1}$ and early-life stress may be responsible for the observed functional alterations.

\section{Potential link between CRF-CRF ${ }_{1}$ and neurexin-neuroligin may modulate the effects of stress on synaptic plasticity, learning and memory}

Excitatory and inhibitory synapses are modulated by the neurexin-neuroligin complex (Südhof, 2008). Neurexins are a family of synaptic cell adhesion molecules which primarily localize at presynaptic sites, while postsynaptic neuroligins abound in and act on excitatory and inhibitory synapses (Chubykin et al., 2007). Recently, the neurexin-neuroligin complex has been implicated in cognitive diseases (Jamain et al., 2003; Kim et al., 2008; Rujescu et al., 2009), and studies in mutant mice highlight their importance in synaptic transmission and cognition (Etherton et al., 
2009; Blundell et al., 2010; Dahlhaus et al., 2010). In stressed wild-type mice, both neurexin-1 and neuroligin-3 mRNA levels were reduced, whereas only neuroligin-3 was decreased in stressed $\mathrm{CRF}_{1}-\mathrm{CKO}$ mice. Hence, neurexins and neuroligins are potential molecular substrates which may partly mediate the effects of early-life stress on synaptic plasticity and cognition. Furthermore, the colocalization of $\mathrm{CRF}_{1}$ with neurexins raises the possibility that the CRF-CRF ${ }_{1}$ system interacts with the neurexinneuroligin complex to modulate synaptic activity.

The current study also has a few limitations. First, the overexpression of forebrain CRF augments both $\mathrm{CRF}_{1}$ and $\mathrm{CRF}_{2}$ signaling, and thus is not exactly the opposite of forebrain $\mathrm{CRF}_{1}$ deficiency. The involvements of $\mathrm{CRF}_{2}$ signaling and the innervation of other brain regions by forebrain $\mathrm{CRF}$ in shaping the cognitive phenotype of CRF-COE mice cannot be excluded. In addition, genetic mouse models always carry the inherent risk of compensatory mechanisms, which might affect the observed phenotype. Third, as we examined the expression of several synaptic proteins at 1 week after the behavioral tests, the potential influences of testing on the expression changes should be considered when interpreting the data. Finally, although the impact of individual housing on the behavioral profile of male mice remains a matter of debate (Arndt et al., 2009; Bartolomucci et al., 2009), one should keep in mind that single housing of mice may alter their behavior and interact with early-life experience and genotype to contribute to the observed findings, which merits future studies.

Together, we provide evidence that forebrain $\mathrm{CRF}_{1}$ signaling mediates, at least in part, the programming effects of early-life stress on cognition. Intriguingly, forebrain $\mathrm{CRF}_{1}$ inactivation enhances the function of specific neuronal networks after postnatal stress exposure, such as LTP and spine density in CA1. Manipulation of forebrain $\mathrm{CRF}_{1}$ may be a promising therapeutic strategy to abate the deleterious consequences of early-life stress on cognition and conceivably, to prevent or delay the onset of early-life stress-related psychiatric disorders.

\section{References}

Aisa B, Tordera R, Lasheras B, Del Río J, Ramírez MJ (2007) Cognitive impairment associated to HPA axis hyperactivity after maternal separation in rats. Psychoneuroendocrinology 32:256-266.

Aldenhoff JB, Gruol DL, Rivier J, Vale W, Siggins GR (1983) Corticotropin releasing factor decreases postburst hyperpolarizations and excites hippocampal neurons. Science 221:875-877.

Arndt SS, Laarakker MC, van Lith HA, van der Staay FJ, Gieling E, Salomons AR, van't Klooster J, Ohl F (2009) Individual housing of mice-impact on behaviour and stress responses. Physiol Behav 97:385-393.

Avishai-Eliner S, Yi SJ, Baram TZ (1996) Developmental profile of messenger RNA for the corticotropin-releasing hormone receptor in the rat limbic system. Brain Res Dev Brain Res 91:159-163.

Avishai-Eliner S, Brunson KL, Sandman CA, Baram TZ (2002) Stressedout, or in (utero)? Trends Neurosci 25:518-524.

Bagot RC, van Hasselt FN, Champagne DL, Meaney MJ, Krugers HJ, Joëls M (2009) Maternal care determines rapid effects of stress mediators on synaptic plasticity in adult rat hippocampal dentate gyrus. Neurobiol Learn Mem 92:292-300.

Bartolomucci A, Cabassi A, Govoni P, Ceresini G, Cero C, Berra D, Dadomo H, Franceschini P, Dell'Omo G, Parmigiani S, Palanza P (2009) Metabolic consequences and vulnerability to diet-induced obesity in male mice under chronic social stress. PLoS One 4:e4331.

Blundell J, Blaiss CA, Etherton MR, Espinosa F, Tabuchi K, Walz C, Bolliger MF, Südhof TC, Powell CM (2010) Neuroligin-1 deletion results in impaired spatial memory and increased repetitive behavior. J Neurosci 30:2115-2129.

Bradley RG, Binder EB, Epstein MP, Tang Y, Nair HP, Liu W, Gillespie CF, Berg T, Evces M, Newport DJ, Stowe ZN, Heim CM, Nemeroff CB, Schwartz A, Cubells JF, Ressler KJ (2008) Influence of child abuse on adult depression: moderation by the corticotropin-releasing hormone receptor gene. Arch Gen Psychiatry 65:190-200.

Brunson KL, Eghbal-Ahmadi M, Bender R, Chen Y, Baram TZ (2001) Longterm, progressive hippocampal cell loss and dysfunction induced by early-life administration of corticotropin-releasing hormone reproduce the effects of early-life stress. Proc Natl Acad Sci U S A 98:8856-8861.

Brunson KL, Kramár E, Lin B, Chen Y, Colgin LL, Yanagihara TK, Lynch G, Baram TZ (2005) Mechanisms of late-onset cognitive decline after early-life stress. J Neurosci 25:9328-9338.

Champagne DL, Bagot RC, van Hasselt F, Ramakers G, Meaney MJ, de Kloet ER, Joëls M, Krugers H (2008) Maternal care and hippocampal plasticity: evidence for experience-dependent structural plasticity, altered synaptic functioning, and differential responsiveness to glucocorticoids and stress. J Neurosci 28:6037-6045.

Charney DS, Manji HK (2004) Life stress, genes, and depression: multiple pathways lead to increased risk and new opportunities for intervention. Sci STKE 2004:re5.

Chen Y, Bender RA, Frotscher M, Baram TZ (2001) Novel and transient populations of corticotropin-releasing hormone-expressing neurons in developing hippocampus suggest unique functional roles: a quantitative spatiotemporal analysis. J Neurosci 21:7171-7181.

Chen Y, Brunson KL, Adelmann G, Bender RA, Frotscher M, Baram TZ (2004a) Hippocampal corticotropin releasing hormone: pre- and postsynaptic location and release by stress. Neuroscience 126:533-540.

Chen Y, Bender RA, Brunson KL, Pomper JK, Grigoriadis DE, Wurst W, Baram TZ (2004b) Modulation of dendritic differentiation by corticotropin-releasing factor in the developing hippocampus. Proc Natl Acad Sci U S A 101:15782-15787.

Chen Y, Fenoglio KA, Dubé CM, Grigoriadis DE, Baram TZ (2006) Cellular and molecular mechanisms of hippocampal activation by acute stress are age-dependent. Mol Psychiatry 11:992-1002.

Chen Y, Dubé CM, Rice CJ, Baram TZ (2008) Rapid loss of dendritic spines after stress involves derangement of spine dynamics by corticotropinreleasing hormone. J Neurosci 28:2903-2911.

Chen Y, Rex CS, Rice CJ, Dubé CM, Gall CM, Lynch G, Baram TZ (2010) Correlated memory defects and hippocampal dendritic spine loss after acute stress involve corticotropin-releasing hormone signaling. Proc Natl Acad Sci U S A 107:13123-13128.

Chubykin AA, Atasoy D, Etherton MR, Brose N, Kavalali ET, Gibson JR, Südhof TC (2007) Activity-dependent validation of excitatory versus inhibitory synapses by neuroligin-1 versus neuroligin-2. Neuron 54:919-931.

Dahlhaus R, Hines RM, Eadie BD, Kannangara TS, Hines DJ, Brown CE, Christie BR, El-Husseini A (2010) Overexpression of the cell adhesion protein neuroligin-1 induces learning deficits and impairs synaptic plasticity by altering the ratio of excitation to inhibition in the hippocampus. Hippocampus 20:305-322.

de Kloet ER, Oitzl MS, Joëls M (1999) Stress and cognition: are corticosteroids good or bad guys? Trends Neurosci 22:422-426.

Etherton MR, Blaiss CA, Powell CM, Südhof TC (2009) Mouse neurexinlalpha deletion causes correlated electrophysiological and behavioral changes consistent with cognitive impairments. Proc Natl Acad Sci U S A 106:17998-18003.

Evans GW, Schamberg MA (2009) Childhood poverty, chronic stress, and adult working memory. Proc Natl Acad Sci U S A 106:6545-6549.

Feder A, Nestler EJ, Charney DS (2009) Psychobiology and molecular genetics of resilience. Nat Rev Neurosci 10:446-457.

Fenoglio KA, Brunson KL, Avishai-Eliner S, Stone BA, Kapadia BJ, Baram TZ (2005) Enduring, handling-evoked enhancement of hippocampal memory function and glucocorticoid receptor expression involves activation of the corticotropin-releasing factor type 1 receptor. Endocrinology 146:4090-4096.

Fenoglio KA, Brunson KL, Baram TZ (2006) Hippocampal neuroplasticity induced by early-life stress: functional and molecular aspects. Front Neuroendocrinol 27:180-192.

Gabbott PL, Somogyi J (1984) The 'single' section Golgi-impregnation procedure: methodological description. J Neurosci Methods 11:221-230.

Heinrichs SC, Stenzel-Poore MP, Gold LH, Battenberg E, Bloom FE, Koob GF, Vale WW, Pich EM (1996) Learning impairment in transgenic mice with central overexpression of corticotropin-releasing factor. Neuroscience 74:303-311.

Ivy AS, Rex CS, Chen Y, Dubé C, Maras PM, Grigoriadis DE, Gall CM, Lynch 
G, Baram TZ (2010) Hippocampal dysfunction and cognitive impairments provoked by chronic early-life stress involve excessive activation of CRH receptors. J Neurosci 30:13005-13015.

Jamain S, Quach H, Betancur C, Råstam M, Colineaux C, Gillberg IC, Soderstrom H, Giros B, Leboyer M, Gillberg C, Bourgeron T (2003) Mutations of the X-linked genes encoding neuroligins NLGN3 and NLGN4 are associated with autism. Nat Genet 34:27-29.

Joëls M, Baram TZ (2009) The neuro-symphony of stress. Nat Rev Neurosci 10:459-466.

Joëls M, Pu Z, Wiegert O, Oitzl MS, Krugers HJ (2006) Learning under stress: how does it work? Trends Cogn Sci 10:152-158.

Kamphuis PJ, Gardoni F, Kamal A, Croiset G, Bakker JM, Cattabeni F, Gispen WH, van Bel F, Di Luca M, Wiegant VM (2003) Long-lasting effects of neonatal dexamethasone treatment on spatial learning and hippocampal synaptic plasticity: involvement of the NMDA receptor complex. FASEB J 17:911-913.

Kim HG, Kishikawa S, Higgins AW, Seong IS, Donovan DJ, Shen Y, Lally E, Weiss LA, Najm J, Kutsche K, Descartes M, Holt L, Braddock S, Troxell R, Kaplan L, Volkmar F, Klin A, Tsatsanis K, Harris DJ, Noens I, et al. (2008) Disruption of neurexin 1 associated with autism spectrum disorder. Am J Hum Genet 82:199-207.

Kim JJ, Diamond DM (2002) The stressed hippocampus, synaptic plasticity and lost memories. Nat Rev Neurosci 3:453-462.

Korosi A, Baram TZ (2009) The pathways from mother's love to baby's future. Front Behav Neurosci 3:27.

Korosi A, Shanabrough M, McClelland S, Liu ZW, Borok E, Gao XB, Horvath TL, Baram TZ (2010) Early-life experience reduces excitation to stressresponsive hypothalamic neurons and reprograms the expression of corticotropin-releasing hormone. J Neurosci 30:703-713.

Lin HJ, Huang CC, Hsu KS (2006) Effects of neonatal dexamethasone treatment on hippocampal synaptic function. Ann Neurol 59:939-951.

Lu A, Steiner MA, Whittle N, Vogl AM, Walser SM, Ableitner M, Refojo D, Ekker M, Rubenstein JL, Stalla GK, Singewald N, Holsboer F, Wotjak CT, Wurst W, Deussing JM (2008) Conditional mouse mutants highlight mechanisms of corticotropin-releasing hormone effects on stress-coping behavior. Mol Psychiatry 13:1028-1042.

Lupien SJ, McEwen BS, Gunnar MR, Heim C (2009) Effects of stress throughout the lifespan on the brain, behaviour and cognition. Nat Rev Neurosci 10:434-445.

Lynch MA (2004) Long-term potentiation and memory. Physiol Rev 84:87-136.

Müller MB, Zimmermann S, Sillaber I, Hagemeyer TP, Deussing JM, Timpl P, Kormann MS, Droste SK, Kühn R, Reul JM, Holsboer F, Wurst W (2003) Limbic corticotropin-releasing hormone receptor 1 mediates anxiety-related behavior and hormonal adaptation to stress. Nat Neurosci 6:1100-1107.

Oitzl MS, Workel JO, Fluttert M, Frösch F, De Kloet ER (2000) Maternal deprivation affects behaviour from youth to senescence: amplification of individual differences in spatial learning and memory in senescent Brown Norway rats. Eur J Neurosci 12:3771-3780.

Oitzl MS, Champagne DL, van der Veen R, de Kloet ER (2010) Brain development under stress: hypotheses of glucocorticoid actions revisited. Neurosci Biobehav Rev 34:853-866.

O'Malley D, Dinan TG, Cryan JF (2011) Neonatal maternal separation in the rat impacts on the stress responsivity of central corticotropinreleasing factor receptors in adulthood. Psychopharmacology (Berl) 214:221-229.

Oomen CA, Soeters H, Audureau N, Vermunt L, van Hasselt FN, Manders EM, Joëls M, Lucassen PJ, Krugers H (2010) Severe early life stress hampers spatial learning and neurogenesis, but improves hippocampal syn- aptic plasticity and emotional learning under high-stress conditions in adulthood. J Neurosci 30:6635-6645.

Paxinos G, Watson C (2001) The mouse brain in stereotaxic coordinates, Ed 2. San Diego: Academic.

Radulovic J, Rühmann A, Liepold T, Spiess J (1999) Modulation of learning and anxiety by corticotropin-releasing factor (CRF) and stress: differential roles of CRF receptors 1 and 2. J Neurosci 19:5016-5025.

Refojo D, Schweizer MC, Kühne C, Ehrenberg S, Thoeringer CK, Vogl AM, Dedic N, Schumacher M, von Wolff G, Avrabos C, Touma C, Engblom D, Schütz G, Nave KA, Eder M, Wotjak CT, Sillaber I, Holsboer F, Wurst W, Deussing JM (2011) Glutamatergic and dopaminergic neurons mediate anxiogenic and anxiolytic effects of CRHR1. Science, in press.

Rice CJ, Sandman CA, Lenjavi MR, Baram TZ (2008) A novel mouse model for acute and long-lasting consequences of early life stress. Endocrinology 149:4892-4900.

Row BW, Dohanich GP (2008) Post-training administration of corticotropinreleasing hormone $(\mathrm{CRH})$ enhances retention of a spatial memory through a noradrenergic mechanism in male rats. Neurobiol Learn Mem 89:370-378.

Rujescu D, Ingason A, Cichon S, Pietiläinen OP, Barnes MR, Toulopoulou T, Picchioni M, Vassos E, Ettinger U, Bramon E, Murray R, Ruggeri M, Tosato S, Bonetto C, Steinberg S, Sigurdsson E, Sigmundsson T, Petursson H, Gylfason A, Olason PI, et al. (2009) Disruption of the neurexin 1 gene is associated with schizophrenia. Hum Mol Genet 18:988-996.

Sadowski H, Ugarte B, Kolvin I, Kaplan C, Barnes J (1999) Early life family disadvantages and major depression in adulthood. Br J Psychiatry 174:112-120.

Schenkel LS, Spaulding WD, DiLillo D, Silverstein SM (2005) Histories of childhood maltreatment in schizophrenia: relationships with premorbid functioning, symptomatology, and cognitive deficits. Schizophr Res 76:273-286.

Schmidt MV (2010) Molecular mechanisms of early life stress-lessons from mouse models. Neurosci Biobehav Rev 34:845-852.

Schmidt MV, Sterlemann V, Ganea K, Liebl C, Alam S, Harbich D, Greetfeld M, Uhr M, Holsboer F, Müller MB (2007) Persistent neuroendocrine and behavioral effects of a novel, etiologically relevant mouse paradigm for chronic social stress during adolescence. Psychoneuroendocrinology 32:417-429.

Sheng H, Zhang Y, Sun J, Gao L, Ma B, Lu J, Ni X (2008) Corticotropinreleasing hormone $(\mathrm{CRH})$ depresses $N$-methyl-D-aspartate receptormediated current in cultured rat hippocampal neurons via CRH receptor type 1. Endocrinology 149:1389-1398.

Smoller JW, Yamaki LH, Fagerness JA, Biederman J, Racette S, Laird NM, Kagan J, Snidman N, Faraone SV, Hirshfeld-Becker D, Tsuang MT, Slaugenhaupt SA, Rosenbaum JF, Sklar PB (2005) The corticotropinreleasing hormone gene and behavioral inhibition in children at risk for panic disorder. Biol Psychiatry 57:1485-1492.

Sterlemann V, Rammes G, Wolf M, Liebl C, Ganea K, Müller MB, Schmidt MV (2010) Chronic social stress during adolescence induces cognitive impairment in aged mice. Hippocampus 20:540-549.

Südhof TC (2008) Neuroligins and neurexins link synaptic function to cognitive disease. Nature 455:903-911.

Tyrka AR, Price LH, Gelernter J, Schepker C, Anderson GM, Carpenter LL (2009) Interaction of childhood maltreatment with the corticotropinreleasing hormone receptor gene: effects on hypothalamic-pituitaryadrenal axis reactivity. Biol Psychiatry 66:681-685.

Wang XD, Chen Y, Wolf M, Wagner KV, Liebl C, Scharf SH, Harbich D, Mayer B, Wurst W, Holsboer F, Deussing JM, Baram TZ, Müller MB, Schmidt MV (2011) Forebrain CRHR1 deficiency attenuates chronic stress-induced cognitive deficits and dendritic remodeling. Neurobiol Dis 42:300-310. 